\title{
Small-Urban-Spaces 内外の行為からみた SUS 領域の形成: FORMATION OF SUS-TERRITORIES FROM VIEW POINTS OF PEDESTRIAN BEHAVIOR IN SMALL-URBAN-SPACES
}

\author{
近江 隆*, 北原啓司**. \\ Takashi OMI and Keiji KITAHARA
}

\begin{abstract}
We already studied on SUS (Small-Urban-Spaces), form and formative factor in preceding paper. In this paper, we analyze pedestrian behavior in SUS and frontage street, and deal with possibility of SUS, private territory, playing important role as openspaces for people by interaction with street, public territory.

Scale and form of SUS have an effect on pedestrian behavior in relation to presence and situation of sales wagon or signboard in SUS and street furniture. And they form Semi-Private spaces in street and Semi-Public spaces in SUS, and SUS-Territory make its appearance. This movement affect frontage street and lead to public behavior, what is called SUS-Effect, and extension of SUS-Territory have an effect on street activity.
\end{abstract}

Keywords : Small-Urban-Spaces, setback, Semi-Private, Semi-Public, openspaces スモールアーバンスペース，壁面後退，セミ・プライベート，七ミ・パブリック，空 地

\section{1. 研究の目的}

近年, 地価の高騰が大きな社会問題となっているなか, 都心部では高密化・高層化が進んでおり，それに伴って 欧米のようにオープンスペースを新たに設置することは 困難な状況にある。また，個々に建設される建物の内部 空間は，高度な建築技術により計画的に熟慮されている のに対し，敷地内の外部空間は単に残余空間として扱わ れてきている。このような状沉のなかで，総合設計制度 に基づく公開空地等が見られるようになり，それらの実 態等については研究されているものの，オープンスペー スとしての効果についてはそれほど解明されておら ず湆，結果的に容積率緩和のための手段としての側面 のみが強調される形となっている。

そこで，先の報告において，都市内の小公園や公開空 地等のオープンスペースの有効性を認めつつも，私的な 建物の建設とともに生み出されてくる建物および敷地内 にあるオープンスペースを「Small-Urban-Spaces（以 下 SUS)」と定義し, 仙台市中心部商店街の調査結果か らその形態と形成要因について論じだ氵21。

実際の街路には大小様々な無数の凹凸 (SUS) が存 在しており，その分布状洗や個々のSUS の空間形態は,
それぞれの街路の特性を示す有効な分析指標となること が明らかにされたが，このようなSUSの存在は，SUS 内外で展開される人々の行為を大きく左右し; 街路上に おける淀みや賑わいなどの様相の差を引き起こすもので あると考えられる。

ここでは, 私的領域の一部である SUS が街路と接す ることによって，公的領域の広がりを SUS 内に誘引す る一方, 私的領域の街路への進出を同時に成立させる， SUS 亡街路の相互作用を, SP 化 (SPu化・SPr 化) という概念注3を用いて記述し，SPu 化および SPr 化の 交換関係の成立として明らかにする。

そこで，特に本論では，SUS と街路の歩行者とが作 り出す空間パターン, 領域性とその意味・役割に，歩行 者の行為面から着目し，私的空間としてのSUS が独自 に持つ空間の意味之, 公的空間との相冝作用の上に形成 される機能の誘引・発生, 新しい領域 [SUS 領域] の 形成を明らかにするものである。

\section{2. 課題と方法}

本報告は，SUS 領域が形成されると考えられる範囲， すなわち SUS の内部および前面街路上の人々の行動の
* 東北大学工学部建築学科 助教授 $\cdot$ 工博

** 東北大学工学部建築学科 助手. I.修
Assoc. Prof., Dept. of Architecture, Faculty of Engineering, Univ. of Tohoku, Dr. Eng.

Research Assoc., Dept. of Architecture, Faculty of Engineering, Univ. of Tohoku, M. Eng. 
種類および位置, 行為者の属性, 行為に関与したもの(要 素)，および動線を一定時間内にトポロジカルな関係と して地図上に記録し,図一1に示すような『行動観察マッ プ』这1 の分析から，SPu化・SPr 化の実態を分析する とともに, SUS 規模の拡大にともなう, SUS 領域の外 延化あるいはSUS 効果注5とも呼ぶべき現象を明らかに する。

なお, 本報告は, 仙台市における調查結果 (調查 No. 2) をもとに分析したものである注6)。また, SUS 領域内の 場所性および領域形成と構成要素との関係性について は, 中規模以上の SUS を中心に実施した横浜市・吉祥 寺市の調查結果を加えて, さらに分析を進めており，続 報で詳細に報告する ${ }^{1) ~ 8) 。 ~}$

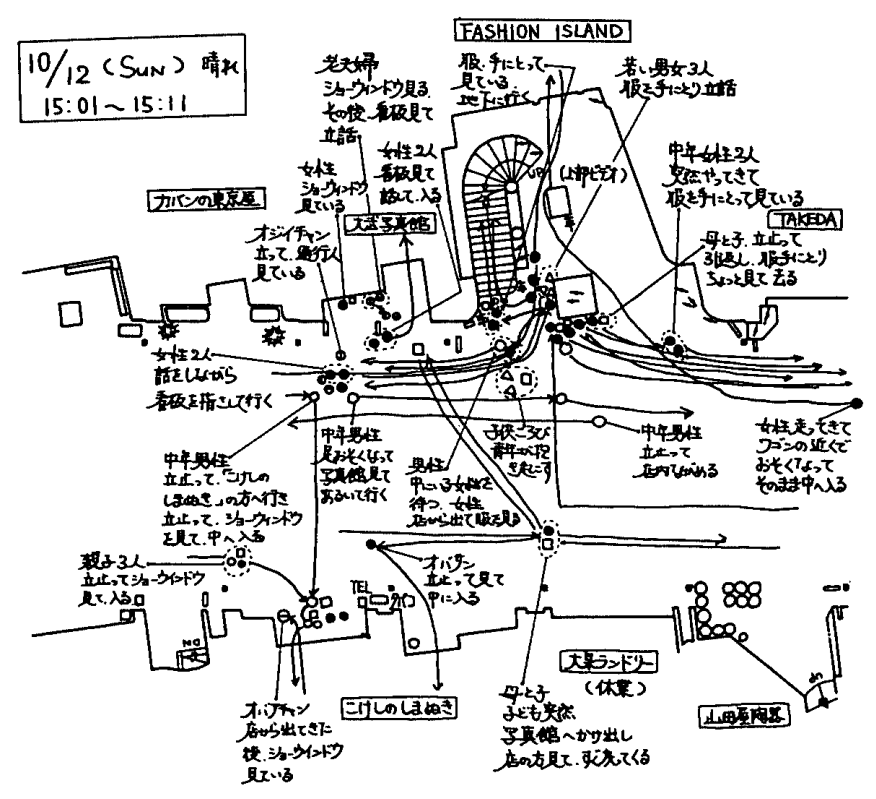

図一1 行動観察マップ $(1 / 500)$

\section{（1）調査方法}

仙台市一番町一番街, 一番町 4 丁目商店街, 大町商店 街および一番町サンモールの一部店舗を調査対象とし て, 各街路とも晴天または晨の日（平日）の午後 2 時か ら 4 時に, 1 か所 10 分間の観察調查を実施し, 対象 SUS の内部および前面街路において発生する行為の種 類, 行為者の動線・属性, その他気ついた点を, あらか じめ作成した図面（縮尺 1/150）に記入し，また記入漏 れを防ぐために，同時にビデオ撮影も実施した。

このようにとて作成した観察マップ数は158例の SUS（奥行き $50 \mathrm{~cm}$ 末満の「SUSなし」を含む）につ いて, 67 シートとなっている ${ }^{\text {市? }}$

\section{(2) SUS内外に発生する行為}

行動観察調査結果の分析は, SUS 内部および前面街 路上での歩行者の行為を, 次の 6 つの行為に類型化し, 行う。

(1) TAKE : SUS内外のワゴンや商品にとりつき, 商 品を手にとる。
(2) WATCH : ショーウインドウやインフォメイション に見入る。

(3)WAIT : SUS内外で人を待つ。待ち合わせの場合 と店内で買い物をする人を外で待つケー スとがある。

(4) USE : 公共的な設置物（ストリートファニチュ ア）を利用する。

(5) STOP：SUS の内外で立ち止まったり，立ち話を する。購買行動とは無関係な行為。

(6) SEE : SUS内外のショーウインドウや看板, ポ スター等を眺めながら通り過ぎる。

次に図一1に示した行動観察マップをもとに, 同じ行 為類型同士を空間的にまとめ, 行為の種類とその発生場 所を，図中の凡例を用いて模式的に表現し，SUS 内外 の空間要素も, 記号化した上で図示した『行為類型分析 マップ』を作成する(図一2)。

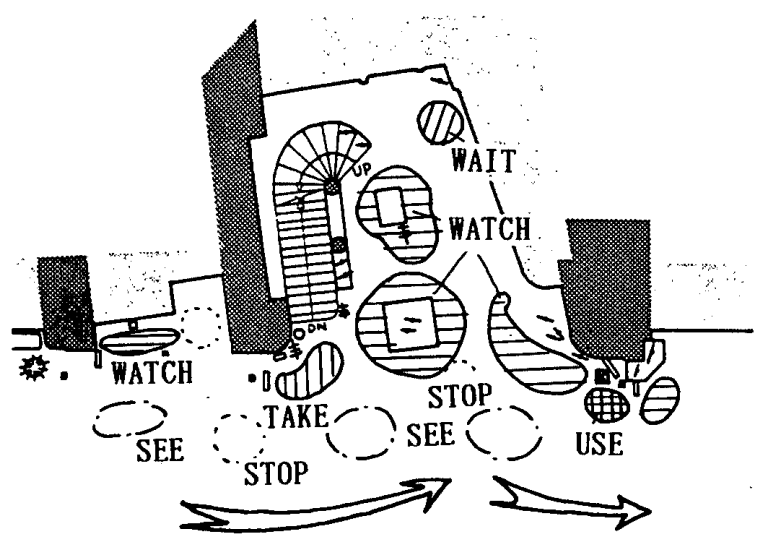

図一2 行為類型分析マップ $(1 / 400)$

分析の次なる段階として, 行為類型分析マップをもと に，PSUS 領域マップ』を作成する。これは，商業活動 に付随するプライベートな行為 (TAKE, WATCH), 歩行者が店舗とは無関係に繰り広げるパブリックな行為 (WAIT, STOP, USE, SEE) が, SUS 内外の空間の どの位置で発生しているか，またそれがどのような空間 要素 (内部設置物, ストリートファニチュア等) と関係 して生じているか，そして歩行動線にいかなる影響を与 えているかといった観点から，SPu化・SPr 化を判別 し, SUS 領域を推定し, 表現するマップである(図一3)。 ここでの研究手法は，観察マップの分析を通じて，発 生行為の量的関係を統計処理によって解明するというも のではなく，個々の行動観察マップにおいて，空間要素 (物)，歩行者の動線および行為の発生状況から行為分 布領域を判定し，本来目に見えぬ概念である『SUS 領域』 を顕在化させようとするものである。したがって，領域 図の作成においては, 行為の量的な密度で SPu 化· SPr 化を判断するというのではなく，行為の発生した 最大の範囲を領域としている。 


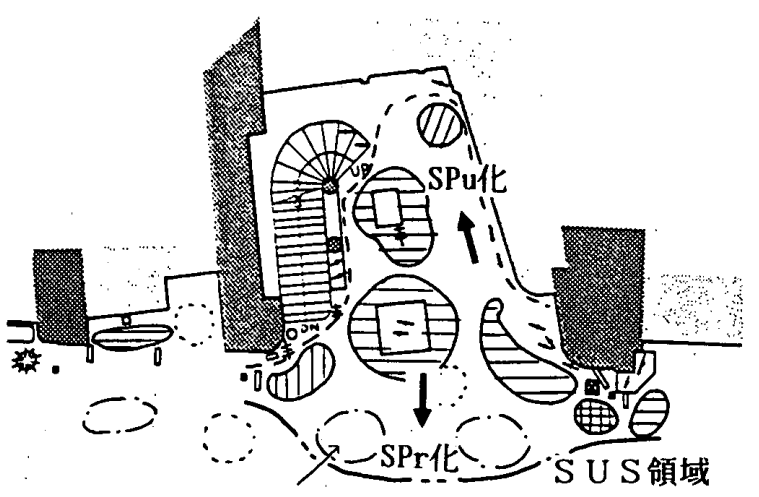

$\mathrm{S} U \mathrm{~S}$ 効果

图一3 SUS 領域マップ $(1 / 400)$

$$
\begin{aligned}
& \mathrm{Pr} \cdot \mathrm{Pu} \text { 行為の分布、频行動線の記述 } \\
& \downarrow \text { [行動僬察マップ] } \\
& \text { 記号化 } \\
& 1 \text { [行為精型分析マッフ] }
\end{aligned}
$$

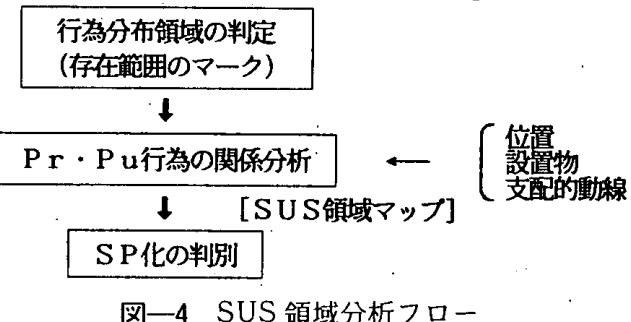

図一4 SUS 領域分析フロー

\section{3. 行為からみた SUS 領域の形成}

（1）SUS の形態類型と.SP 化

まず，前報で類型化したSUS の空間形態と関連させ て, 行為を通してSUS と街路の間に形成されるSUS 領域を上記の方法により解明する。

なお，SUS の空間形態は，形そのものだけでなく， ある程度の空間の具体的形態要素を一つのセットとして 含んでいる。例えば，クローズ型はショーウインドウ形 式，セールス型はワゴン等の物販用具を使う形である。 これらの分析結果は，各事例で全く同一のものとはなり 得ないが，共通した傾向として生起する現象に着目しな がら，パターンとして整理することができる。ここでの 結果の表現は，こうしたパターンの代表的事例を範例と して示したものである（縮尺はすべて 1/400）。

(1) SUSなし（奥行き $50 \mathrm{~cm}$ 未満の小規模 SUS を含 む位防)

調查事例 18 のうち，何の行為も発生しないものが 9 例に達する。そのうち 1 例を除いて, 商業系ファニチュ ア (ワゴン等) も存在しない何もない空間であり，歩行 者は店舗の前を通り過ぎるだけである（図一-5）。
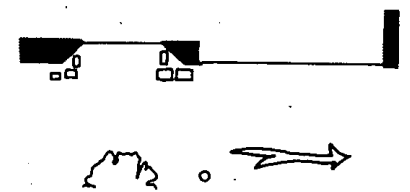

図一5 SUSなし一商業系ファニチュアなし
行為がみられた 9 例のうち 7 例までは，店堿前面に商 業系ファニチュアが設置されているが，TAKEや WATCH といった商業系行為が観察されたのは半数以 下であり，街路上に立ち止まる(STOP) 例が多くなっ ている。人待ち (WAIT) や歩きながら店舗方向を眺め る行為 (SEE) は全く見られない。店舗敷地内におけ るプライベート行為の発生が少ないだけでなく, 街路上 で行われるパブリックな行為の生起も少なく，新たな SUS 領域は形成されない（図一6）。

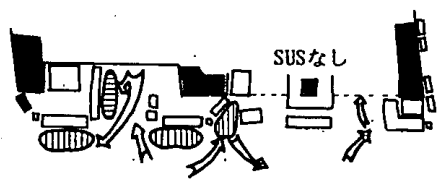

図一6 SUSなし一商業系ファニチュアあり

(2) クローズ型

該当する 4 例すべてが，百貨店のショーウインドウと なっており，立ち止まってウインドウの中を見る行為 (WATCH) がいくつか観察されているが, 街路中央 部の歩行者の視線を吸引するまでの効果はなく，パブ リックな行為は生起しにくい（図一7)。

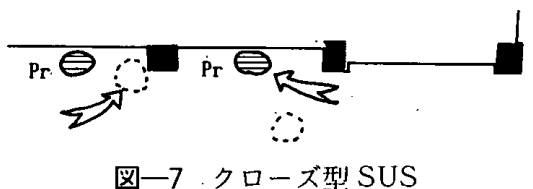

(3) セールス型

小規模な SUS 内から街路にはみ出すような形で，商 業的設置物が存在するセールス型では，これらの商業系 ファニチュアのまわりにとりつく行為として, TAKE やWATCH が多く観察される (17 例/20例)。これら のプライベートな行為は, 街路上にはみ出すことで, $\mathrm{SPr}$ 化を発生させ, STOP のようなパブリックな滞留 型行為の発生も多くみられる。しかし, 商業系設置物は, パブリック行為の侵入に対して同時に障害としても機能 し, SPu 化はSUS の内部梁くまでは生じない。実際, SUS 領域は, 敷地と街路との境界部分からやや街路側 に出た部分にとゼまっている（図一-8）。

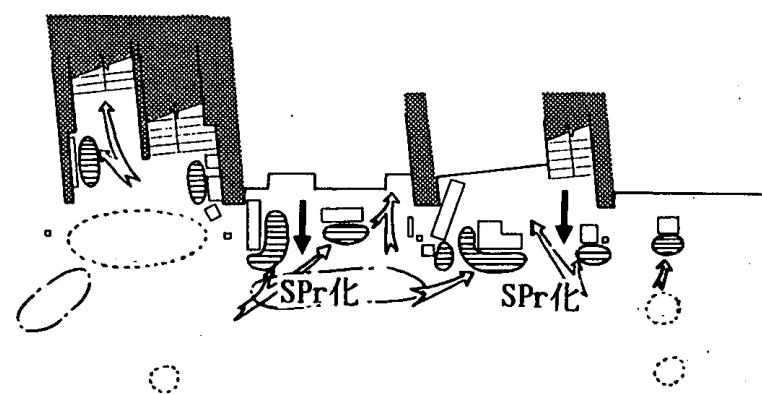

図一8 セールス型SUS 
(4) ポケット型

本報告における調查対象 SUS の約半数（83）を占め るポケット型のSUSにおいては, その行為発生パター ンは以下の 4 つに分けられる（図一9）。

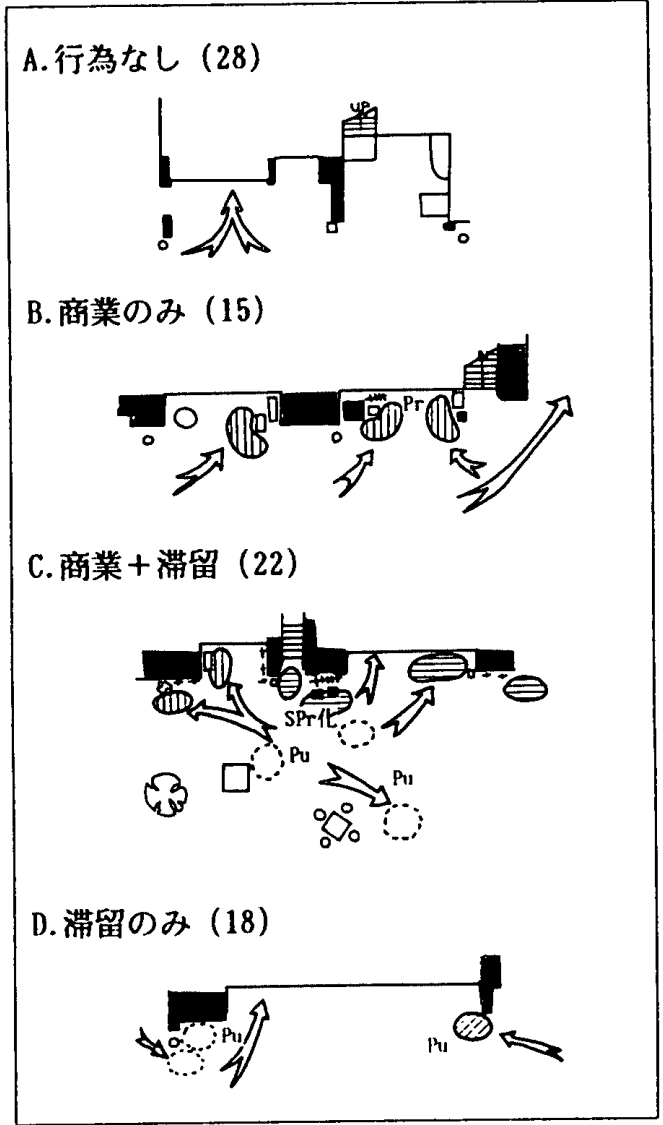

图一9 ポケット型SUS

セールス型と異なり，看板等の情報系ファニチュアは 存在するものの商業系設置物は少ない。ポケット型にお いては,「行為なし」が全体の約 $1 / 3$ となっており, 商 業系のプライベートな行為の発生は, 半数以下である。 セールス型では，プライベートな商業行為が街路にはみ 出しながら, 帯留等のパブリック行為を誘引する形で, SUS 領域が形成されるのに対し, ポケット型では, 商 業系設置物に誘引されるパブリックな行為の発生は全体 の $25 \%$ にとどまる。しかし, 前面部分にワゴン等が設 置されていないことから, 行為全体はSUS の奥深くに まで及び, 滞留等の行為も発生し, 小規模ながらも $\mathrm{SPu}$ 化が進行する。また，それに呼応する形で，前面 街路上でのパブリック行為も活発化すると考えられる。 一方, 商業系のプライベートな行為と関係しない STOP やWAIT が 18 例も存在している事実は（図一 9.D), SUS 独自の誘引作用を示すものであろう。

\section{(5) 通路型}

13 例存在する通路型 SUS は, 奥行きに対し間口は総 じて狭く, 商業系設置物の設置率も低く, SUS 内のプ ライベートな行為の発生も少ない。他のパブリック性を

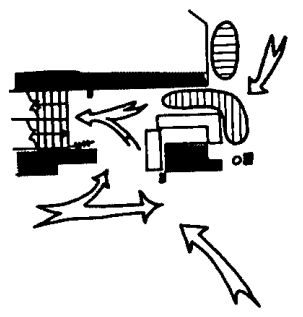

図一10 通路型 SUS

帯びた行為も含めて, 行為の発生量そのものが少なく, $\mathrm{SP}$ 領域の形成が難しい（図一10）。

(6) 占有型

6 例ある占有型の中規模 SUS では，上記小規模 SUS と比べて行為の発生量は一段と増加し, 特に商品が SUS 内に置かれている場合に，それに誘引される TAKE W WATCH といったプライベート行為が增え る。特に，中央部にまとめてアイランド型に商業系設置 物が存在する形態では, 各行為はSUS のかなり奥にま で広がっている（図一11）。街路上では，看板や商品を 見たり，店内から出て行き先を決めるために立ち話をす るといった行為の混在が見られ，店舗前面の狭い範囲で SPr 化が発生している。同時に SUS 内部で, パブリッ ク行為としてのSTOP やWAIT が発生している。この ことは, SUS 規模の増大によって SPr 化・SPu 化の相 互作用が生じ始めることを意味し，そこがセールス型と は基本的に異なるところである。

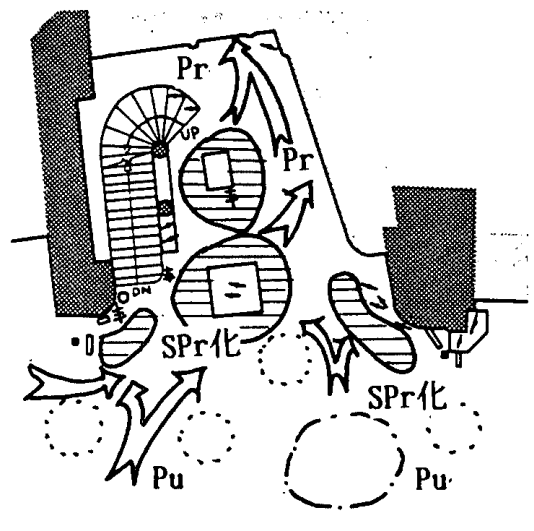

図一11 中規模 SUS (占有型)

\section{(7) 共有型}

中規模 SUS の中でも，共有型の場合はいくつかの店 舗でSUS を共有する形態であるために，占有型と比べ て商業系および情報系の設置物が少なくなっており， TAKE, WATCH の数はセールス型等の小規模 SUS に 比べても少なく, SUS 内のプライベート性はそれほよ゙ 高いものではない。したがって，小規模 SUS でみたよ うな商業系ファニチュアのはみ出しによる前面街路にお ける SPr 化は発生せず，境界部分の曖昧化も生じない。 しかし, SUS そのものは逆にパブリック性を帯び, STOP やWAIT を SUS 内部に誘引し(4 例/6 例), 


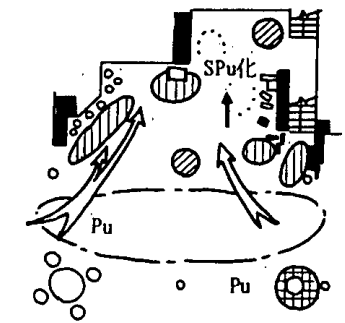

図一12 中規模 SUS (共有型)

$\mathrm{SPu}$ 化は確実に生起している（図一12）。

(8) 複合型

複合型の中規模 SUS は 7 例存在しているが，そのう ち商品などの設置物がほとんど見られず，SUSの奥の 方まで植栽やビデオ等の非商業的設置物が置かれている ケースでは, SUS内のいたるところで人待ちや立ち話 等のパブリック行為がみられ，SPu 化はSUS 全体に広 がることとなる。また，街路中央でも同様の行為が多く みられ，SUS 効果とも言うべき対岸壁や街路樹まわり でのWAITも発生しており, SUS 領域は街路対岸部分 までを含む広い範囲に拡大している（図一13）。

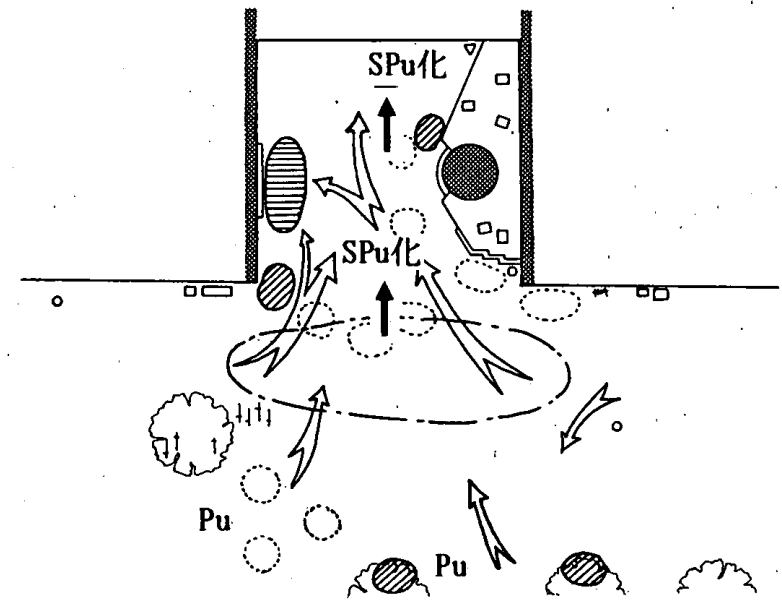

図一13 中規模 SUS (複合型一非商業系設置物)

複合型 SUS で，アイランド的に一か所にまとめて商 品などが置かれ全体的には設置物の少ない夕イプ (3 例) では, SUS 内のプライベート行為はWATCH を中心に してかなりの数が観察されており，それはSUSの前面 の SPr 化を促すこととなる。これに誘引される形で SUS 内を眺める行為や街路樹付近で人待ち, 立ち話と いったパブリック行為が生じており，これは相互作用と して SUS 内への SPu 化が進むことを意味する。概し て, 小規模 SUS と比較して; 滞留型のパブリック行為 の発生が非常に高くなっているのが特徴的である（図一 14)。

\section{(9) 大規模型}

大規模 SUS は，今回の調査においては 2 例しか存在 していないがシ9!，そのうち，内部の広い範囲が商業的 に使われている場合には，その周囲で商業的なプライ

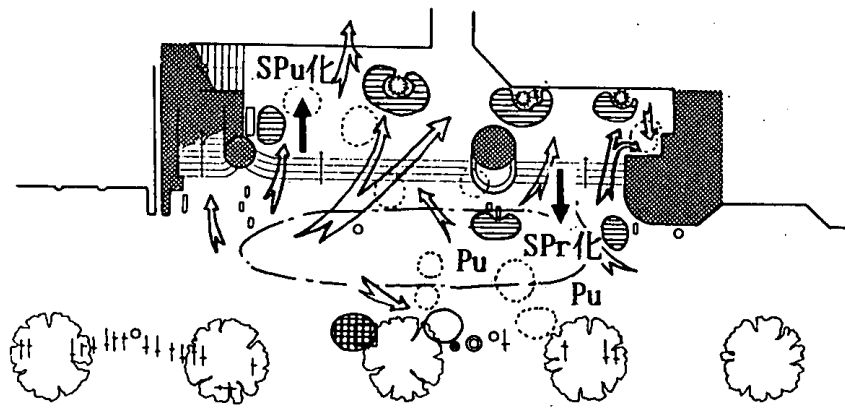

図一14 中規模 SUS (複合型一商業系設置物)

ベート行為が多数発生している。SUS 規模が大きいこ ともあり，敷地からはみ出す形で商業系ファニチュアが 置かれることが少なく，SPr 化の発生は見られない。 街路前面部分ではパブリックな行為が見られるものの, SUS 内部へのSPu 化の浸透はそれほど強いものとは言 えない。したがって, SUS 効果としての街路対岸部分 への SUS 領域の拡大は生じない。この点はSUS と街 路との間に段差があるため，領域の広がりが制約される ことも影響していると考えられる（図一15）。

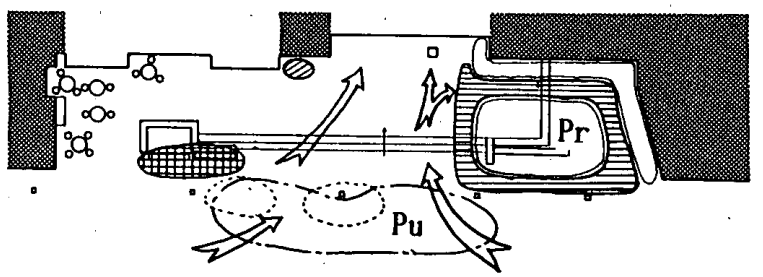

図一15 大規模 SUS一商業系設置物多数

大規模タイプでも，休媳系のシシボル的な設置物（噴 水・オブジェ等) がある場合には, 中規模タイプで見ら れたように，SPu 化はシンボル的設置物の周囲のみな

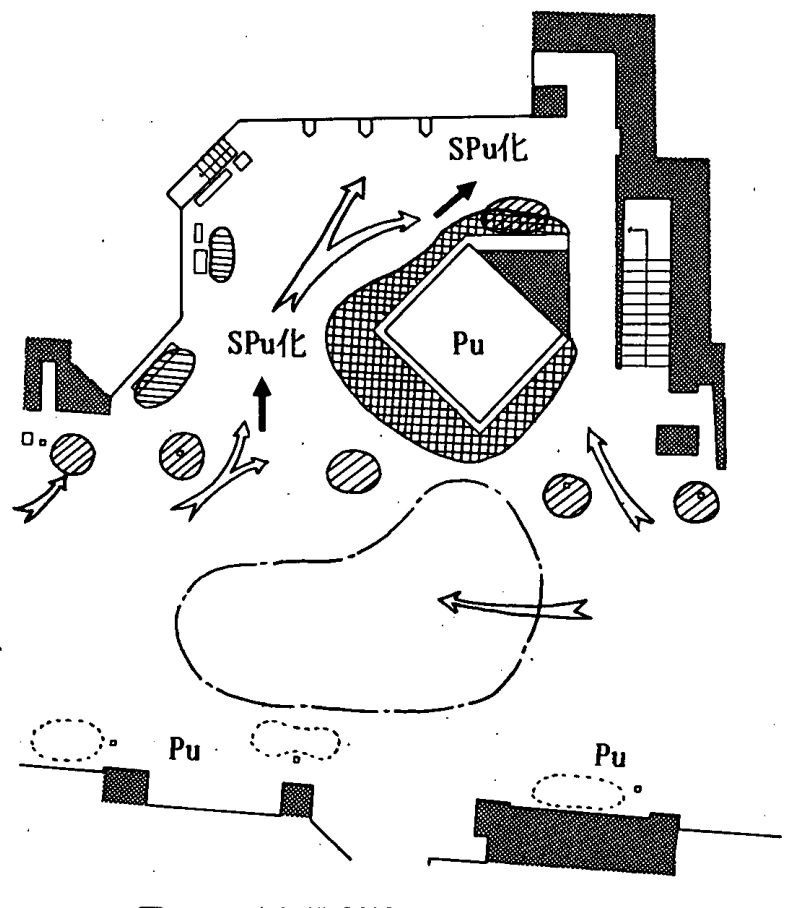

図一16 大規模 SUS-公共系設置物あり 
らず SUS 内全体に広がり，SUS 空間はある意味でパ ブリック化することとなる。そのことは, 街路部分と SUS とがパブリックな空間として接続することを意味 しており, 街路対岸においていくつかの行為（WAIT, STOP, SEE) も観察され, 街路全体の広い範囲で SUS 効果と言える行為が発生している。このような現 象は，「SUS 領域の外延化」と見なせよう（図一16）。

(2) 空間構成要素と SP 化

上で述べた SUS の 9 つの形態類型を基本に, 本調査 によって抽出されたSUS 内の空間構成要素 (内部条件) および街路上の設置物（外部条件）に対してより詳細な 検討を加え，発生行為との関係を分析する。

内部条件としては, (1)商業系（ショーウインドウ, 商 品・セールスワゴン等)，(2)情報系（看板，案内板等）, (3)公共系 (公衆電話, ビデオ等), また外部条件としては, (1)修景系 (植裁,モニュメント等), (2)休秝・衛生系 (ベ ンチ,テーブル，灰皿等）を取り上げている。

表一1 は，観察調查結果をもとに, SUS の形態類型 別に，上にあげた空間構成要素の有無と SUS 内部およ び前面街路上における行為の発生の有無とをまとめたも のである。

まず商業系の内部条件のうち，ショーウインドウの場 合は, SUS がなく直接街路に面しているタイプでは， ショーウインドウの存在が歩行者の行為とはほとんど関 係なく（8例のうち行為がみられたのは，セールスワゴ ンが併置されたSUS 1 例のみである)，クローズ型にな るとようやく動線は SUS 内に侵入することとなる。 セールス型の場合は, 前面におかれた多様な商業系ファ ニチュアの存在が大きく，ショーウインドウの影響力は 薄いもの之考えられるが，ファニチュアの少ないポケッ 卜型の場合, 約半数の 42 例でショーウインドウは存在 しているが，そのうち 27 例で SEE，STOP 等のパブ リックな行為が発生し，逆にこれらの行為が発生するポ ケット型 SUS のうち, 73 \% がショーウインドウを持っ ている。小規模な SUS であっても，ショーウインドウ まわりでパブリックな行為が発生することとなり，

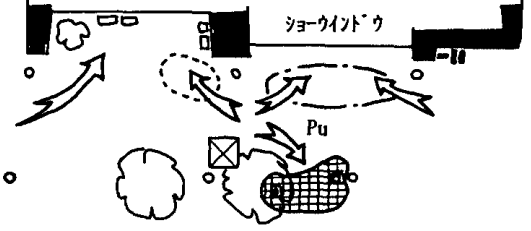

図一17, ショーウインドウと発生行為

SUS 領域は小規模ながら SUS 前面に形成される（図 -17 )。

一方, SUS 内のファニチュアのうち最も数多くみら れる商品 (ハンガー等)，セールスワゴン (図中, $\square$ ) については，直接的に TAKE やWATCH の発生との 関係が強く「SUSなし」17 例のうち行為のあった 8 例中 6 例までが，店舗前面にはみ出す形で設置されてい る商業系ファニチュアにより人の行為を誘引し，歩行者 動線が影響を受けることとなる。また，商業系設置物が 多いセールス型SUS の場合, 当然のことながら商業的 なプライベート行為は数多く発生するが，前面街路上に 滞留等のパブリック行為が発生するケース (10 例) は, すべて商業系ファニチュアが街路にはみ出すほどに多量 に設置されているSUSである。

また，中規模 SUS の場合，商業系設置物が最も多く 存在している占有型では，それらはすべてアイランド型 に設置されており, TAKE やWATCH の数が増加する だけでなく，発生場所もSUS 全体に広がることとなり， 奥深くまで建物非利用者が入り込む例がみられ，SUS 内への SPu 化の浸透に商業系ファニチュアが果たす役 割は，やはり見逃せないものがある（図一18）。

次に，看板等の情報系内部条件（図中，西）が小規

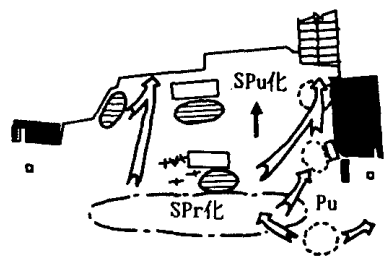

図一18 商業系ファニチュアと発生行為（アイランド型）

表一1 SUS タイプ別空間構成要素と発生行為

\begin{tabular}{|c|c|c|c|c|c|c|c|c|c|c|c|}
\hline & 形鍶祖型 & SUStL & ク-X & セールス & ポケット & 占有 & 共有 & 複合 & 通路 & 大娊模 & 竐 \\
\hline & SUS奏数 & 17 & 4 & 20 & 83 & 6 & 6 & 7 & 13 & 2 & 158 \\
\hline \multirow[t]{3}{*}{ 泟内仆方 } & 埇圆SUS & 8 & 4 & 8 & .42 & 4 & 1 & 1 & 2 & 0 & 70 \\
\hline & Pr行為 & 1 & 2 & 6 & 22 & 3 & 1 & 1 & 2 & 0 & 38 \\
\hline & Pu行為 & 0 & 2 & 4 & 27 & 4 & 0 & 1 & 2 & 0 & 40 \\
\hline \multirow[t]{3}{*}{ 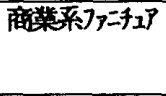 } & 設置SUS & 7. & 0 & 20 & 40 & 5 & 3 & 3 & 6 & 2 & 86 \\
\hline & Pr行為 & 4 & 0 & 17 & 24 & 5 & 2 & 3 & 4 & 2 & 61 \\
\hline & Pu行為 & 2 & 0 & 14 & 17 & 5 & 3 & 3 & 3 & 2 & 49 \\
\hline \multirow[t]{3}{*}{ 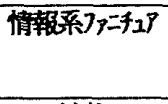 } & 設輯SUS & 2 & 0 & 6 & 21 & 2 & 5 & 5 & .5 & 0 & 46 \\
\hline & Pr行為 & 1 & 0 & 6 & 11 & 2 & 3 & 5 & 3 & 0 & 31 \\
\hline & Pu行為 & 1 & 0 & 6 & 10 & 2 & 5 & 5 & 3 & 0 & 32 \\
\hline \multirow[t]{3}{*}{ 桂戎 } & 設奋SUS & 6 & 0 & 5 & 27 & 0 & 3 & 4 & 3 & 0 & 48 \\
\hline & Pr行為 & 1 & 0 & 3 & 10 & 0 & 2 & 4 & 1 & 0 & 21 \\
\hline & Pu行為 & 1 & 0 & 2 & 8 & 0 & 3 & 4 & 1 & 0 & 19 \\
\hline \multirow[t]{3}{*}{ 休憩系7 $7=f_{1}>$} & 瀷置SUS & 0 & 0 & 0 & 14 & 0 & 1 & 2 & 1 & 0 & 18 \\
\hline & Pr行為 & 0 & 0 & 0 & 10 & 0 & 1 & 2 & 0 & 0 & 13 \\
\hline & Pu行為 & 0 & 0 & 0 & 9 & 0 & 1 & 2 & 1 & 0 & 13 \\
\hline
\end{tabular}


模 SUS 内に存在する場合には，SUS 両脇の出隅部分 に設置されるケースがほとんどであり（21 例/29 例)， 歩行者の動線そのものに影響を与えるには至っていな い。

中規模 SUS.では，本来なら通行上の障害となるよう な中央付近でも，情報系ファニチュアまわりで様々な行 為が観察されており，しかもそこでは商業系ファニチュ アと異なり，人待ちや立ち話（WAIT, STOP) が発生 している。SUS と街路との境界部分に一種のパブリッ ク・スポットが形成され，SPu化が進行している（図 $-19)$ 。

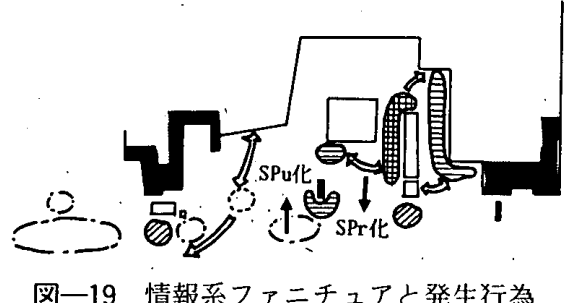

一方, 街路上の構成要素 (外部条件) のうち修景系の 街路樹，植裁について分析すると，SUSなし・小規模 SUS の場合に, 前面街路上の植栽付近では滞留型の行 為はほとんど見られないが(行為が発生している事例は, SUSなしで $1 / 6$ ，ポケット型で $8 / 27)$; 中規模 SUS の 前面の場合には, 共有型, 複合型ともすべての事例で人 待ち (WAIT) や立ち話 (STOP) が見られ, 大規模型 になると街路中央よりも対岸に近い位置の街路樹周囲で あっても, 行為がみられるケースが存在する（図一20, 21)。

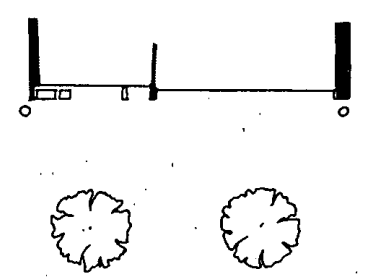

図一20 街路上の植栽と発生行為 (小規模 SUS)

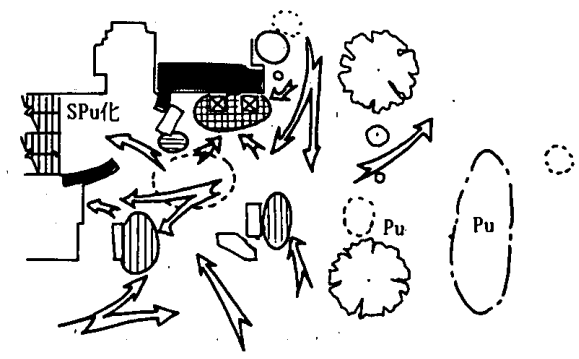

図一21 街路上の植栽と発生行為（中規模 SUS）

また，ベンチ，テーブルの休秝系ファニチュアやごみ 箱・灰血といった衛生系ファニチュアは，小規模 SUS の場合はポケット型の前面街路上でのみ観察されている が，14 例中 4 例が利用されているのみである。中規模
SUSのうち複合型や，大規模 SUS では, SUS 内に休 㮩系ファニチュアが存在していることが多いため, 前面 街路上にこれらのファニチュアはそれほど見られない が, すべての事例で利用は活発であり, SUS 領域の外 延化に寄与することとなっている（図一22）。

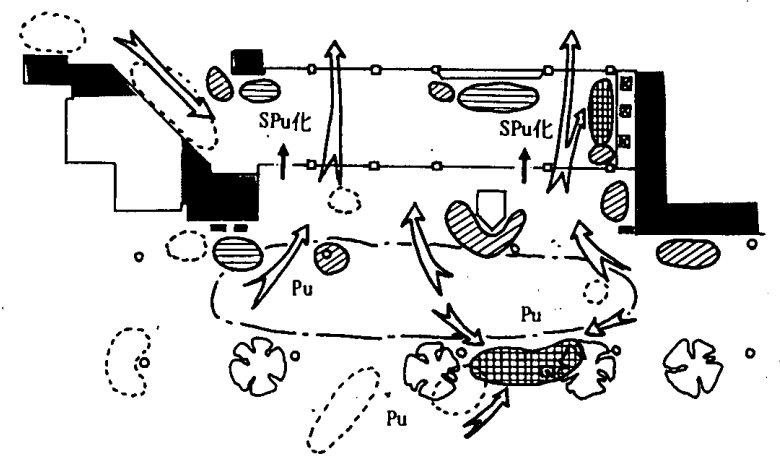

図一22 休秝系ファニチュア（路上）と発生行為

\section{SUS 領域の形成および外延化のメカニズム}

これまでのSUS と街路上に生起した行為と SUS の 空間形態や構成要素との関連から, SUS 領域形成のメ カニズムとその意味について考えてみよう。我々が作成 した「SUS 領域マップ】は, 歩行者の行為内容とその 発生位置および歩行動線の分析により, SPu 化および SPr 化を判別し図中に記入したものであり，SUS 領域 そのものを図示したものではない。SUS 領域は, 固定 されたものではなく,時間とともに変化するものであり， ここでは模式的な表現を用いて, SUS 領域の形成メカ ニズムについて分析するものである。SUS 領域の形成 に関しては，次のような傾向が認められた。

(A) SUSなしの場合，SUS 領域は形成されない。

(B) 小規模 SUSになると、ワゴン等の商業系ファニ チュアのはみ出しによる SPr 化のみが発生し, 街路と の境界部分に SUS 領域が微かに形成される。

(C) SUS が中規模になると，占有型に見られるような 商業系ファニチュアの広範囲にわたる設置は，プライ ベート行為を促進し，店舗前面においてはTAKEゃ WATCH 等の商業的行為が商業系ファニチュアや情報 系ファニチュアのはみ出しに伴って発生することとな る。『公的領域の内部化』としての SPr 化である。これ らの行為は, SUS 規模の拡大にともなって多く観察さ れることとなり, 街路上のパブリック行為 (STOP, WAIT）を誘引しながら SUS 領域は街路中央に向かっ て拡大していくが, SUS 内部においては SPu 化は起こ りにくい。

(D) 同様の中規模 SUS で，商業系の設置物が少なくな ると, SUS 内部のかなり奥まで滞留行為がみられるこ ととなり SPu化が生じ，これに呼応するような形で， SUS 前面の街路上でのパブリック行為は活発化し, SUS 領域の外延化は@を上回ることとなる。 
(E) 中規模 SUS の共有型にみられるように，(Cや(D)の ような商業系設置物がそれほど置かれていない場合は, 公共的な設置物 (ベンチ等) の付近で，『私的領域の外 部化』が進み, SUS はパブリック性を帯び, SPu 化が 生じる。しかし，はみ出しとしての SPr 化はそれほど 見られず，SPr化が誘発するはずの路上のパブリック 行為は生起しにくく, (C)や(D)のような SUS 領域の拡大 は見られない。

(P) 中規模 SUS で複合型に見られるような商業系ファ ニチュアの設置と, ビデオ・電話ボックス等の公共系設 置物亡の共存形態では, SUS 内部の SPu 化は促進され, それが私的領域のはみ出しを誘発し, 街路部分での SPr 化が活発となり, SUS 自体が前面街路のかなり中 心部まで拡大したような形をとる。

(a) 中規模 SUS で, 商業系設置物がアイランド型に一 か所にまとめら机空間的余裕ができると, SUS の奥深 くまでパブリック行為の侵入を受容, 誘引する。それに よって SUS 内全域に広がるSPu化に誘発される形で, SUS 領域の外延化が進む。すなわち SUS 設置による 店舗前面敷地の SPu 化の進行とをれにともなう公私境 界部分の曖昧化が, 公的領域への商業的行為(プライベー 卜）のはみ出しを, 許容, 促進する形となり, 街路上の パブリック行為を活性化しながら, SUS 領域が拡大す ることとなり, Eᄐに比べて大きな SUS 領域が形成され る。

(1) 大規模型 SUS になると，公共系の設置物（電話・

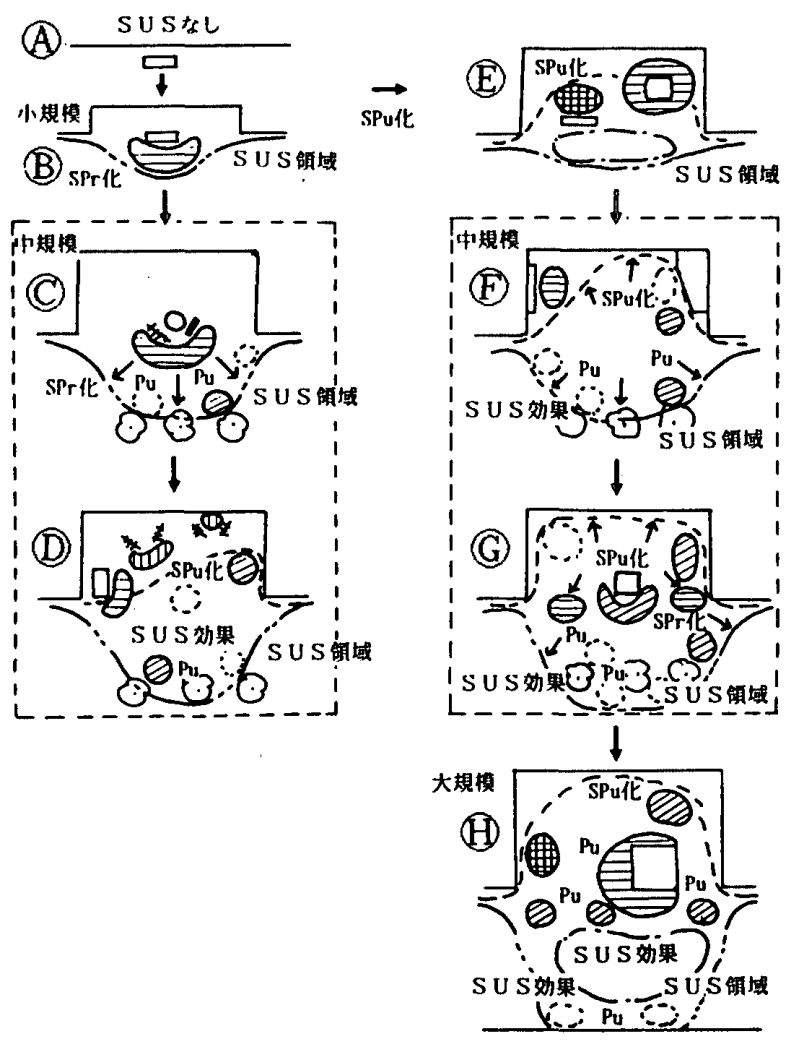

図一23 SUS 領域形成メカニズム
噴水等）や休䄭系ファニチュアがSUS 内に設置される ことが多くなる。これらは，商業的意図が背後にあると はいえ，外部の不特定多数の人々に対して利便を提供す ることとなり，それに呼応する形で，SUS 内の行為は 活発化する。SUS 規模の拡大と，ファニチュアの設置 形態は, 公私境界を変革させ, SPu 化は強化され私的 領域の奥に向かって進み, SUS は公的空間として前面 街路と一体化することとなる。待ち合わせ (WAIT) や 立ち話 (STOP) が SUS の対岸部分で発生することか ら, SUS と前面街路との心理的な一体化が歩行者の行 動パターンに影響を与え, SUS 効果を生起させている。 このように SUS 領域の外延化は街路を巻き込む形で対 岸部分にまで進み, 終結する。

すなわち, SUS 設置者側が SPu 化を受容することが 同時に，公的領域としての街路におけるSUS 領域の外 延化の可能性をより深め, それ故に, 設置者側に反対給 付としてのメリットが与えられると解釉できよう。

\section{5. まとめ}

本報告は, SUS の形態類型とその形成要因について 論じた前報に引き続き，SUS の内部および前面街路上 における人々の行為を分析することにより，私的領域と しての SUS が公的領域との相互作用によって, 都市に おいて不特定多数の人々にとってのオープンスペースと しての役割を担う可能性を論じたものである。

SUS の規模とそれと対応する形態類型が, SUS 内の 設置物の有無およびその位置, 前面街路上のストリート ファニチュアの配置と相互に関連しながら, 行為の発生 状況に影響を与えることとなり, 街路上の SPr 化, SUS 内部での SPu 化を進め, SUS 領域が形成される こととなる。また, 前面街路上にも, その動きは飛び火 することとなり，パブリック行為が誘発されるなどの SUS 効果が生じ, SUS 領域の外延化は街路自体の活性 化にも影響するものと考えられる。

次報では, SUSにおける行為の場所性の検討により 中規模以上の SUS の分析を進め, SUS 領域形成のメ カニズムと領域形成要因との関係を詳細に解明し, 街路 評価におけるSUS の役割を検討する。

なお本報告は, 小室宏二氏 (現いわき市), 山室 真 氏 (現フジ夕工業), 佐藤武志氏 (現三菱地所), 鳥居立 弥氏 (現 NKK), 広瀬浩二君 (大学院生)をはじめと する研究室の多くのスタッフによる共同研究の一部であ り、深く感謝の意を表するものである。

\section{注}

1) 我々が研究の対象とするSUS に関する論文としては, 前報 (「Small-Urban-Spaces の形態と形成要因」, 日本建 築学会計画系論文報告集, No. 424,1991 年) に揭載した 
ように，直接対象の重なるものは存在していない。しかし， 研究のアプローチ的に, また対象とする空間の性格上共 通する研究はいくつか発表されている。公開空地におい て人々の行動に着目した論文としては, 沖塩荘一郎ほか : 公開空地等の実態に関する研究一その 1 . 滞留と通り 抜け利用一(日本建築学会大会学術講演梗概集, 1983 年), 小林英呞ほか; 公開空地の利用者の行動と意識 (日本建 築学会大会学術講演梗概集, 1988 年), また景観的側面 に視点を向けたものとしては, 鳴海邦碩ほか; 建築物景 観の整備についての一考察（日本建築学会大会学術講演 梗概集, 1989 年), 安田丑作ほか; 都市景観形成手法とし ての総合設計制度とその評価に関する研究（日本都市計 画学会学術研究論文集, 1988年) 等が存在している。

2) 近江 隆, 北原啓司：「Small-Urban-Spaces の形態と形 成要因」; 日本建築学会計画系論文報告集, No. 424, 1991 年 6 月

3）近江 隆, 北原啓司, ほか：既成市街地における SP 領 域の形成に関する研究; 日本建築学会大会学術講演梗概 集, 1988 年 10 月

4) Public Streets for Public Use (A VAN NOSTRAN. DREIN HOLD BOOK, 1987) の中では, M. Francisら によって，様々な行動観察マップが紹介されている。

5) SUS 効果; SUS が存在することにより, 人待ち, 立ち 話などのパブリック行為が街路上に誘引され, 街路に賑 わいを創り出す効果。その発生場所は, SUS と街路とが 接する部分から，SUS 対岸部に及ぶケースも見られる。

6）各商店街における調查状洗および仙台市 6 商占街の概要 については，前報において表一1 および表一2に示してあ る。

7）各シート（縮尺 1/150）には，それぞれ6〜8程度の SUSが含まれており, また, 一番町一番街商店街および 一番町 4 丁目商店街においては, 調査日時を変えて同一 SUSにおいて 2 度の行為観察を実施している。2 度の調 査において作成された観察マップは, 調查時点の特殊性 を捨象すべく実施したが，ほとんどのSUSにおいて調 查日時に関係なくほぼ同様の行為が観察されており, 分 析においては, どのSUSにおいても2 回目の調査結果 を用いている。

8） $50 \mathrm{~cm}$ 末満の壁面後退については，実際に外見上は，ほ とんど円み空間としてのSUS と判別できるものはなく, また, そこで行われる行為も, 壁面に密着する形で立つ
ような行為しか見られず，ほとんどの場合，街路上の行 為の延長として発生しているに過ぎないものと見なすこ とができる。民法においても (第 234 条), 敷地境界線か らの距離は $50 \mathrm{~cm}$ 以上とされており, 空間形態と発生行 為との関係性を見る本編の目的から考えて, $50 \mathrm{~cm}$ に満 たないものについては「SUSなし」の範疇に含めること とした。

9）仙台市における調查では, 中規模以上の SUS の例数が 少なく, 昭和 63 年 10 月 3 日 7 日まで実施した横浜市 および吉祥寺市における調查（調查No.5）において，16 例の大規模 SUS を抽出して，仙台における調查事例と 併せて空間構成要素との関係性を，詳細に分析しており， 次稿で報告する予定である。

\section{本論文に関連する既発表論文}

1) 近江 隆, 北原啓司：「SUS-Small Urban Spaces」研究 の課題亡方法, 日本建築学会東北支部研究報告集, 第 50 号, pp. 25 28, 1987 年11月

2）近江 隆, 北原啓司：SUS 空間の SP 化と SUS 効果の 実態, 日本建築学会東北支部研究報告集, 第 50 号, pp. 29 - 32, 1987 年 11 月

3）近江 隆, 北原啓司, 小室宏二, 佐藤武志：SUS 空間の 形態類型と街路評価，日本建築学会東北支部研究報告集, 第 51 号, pp. 149 152, 1988 年 6 月

4）近江 隆, 北原啓司, 小室宏二, 佐藤武志: SUS 領域形 成の要因, 日本建築学会東北支部研究報告集, 第 51 号, pp. $153 \sim 156,1988$ 年 6 月

5) 近江 隆, 北原啓司, 佐藤武志, 鳥居立弥：SUS 空間の 形態類型, 日本建築学会東北支部研究報告集, 第 52 号, pp. 131 134，1989 年 6 月

6）近江 隆, 北原啓司, 佐藤武志, 鳥居立弥：SUSにおけ る行為発生のメカニズム, 日本建築学会東北支部研究報 告集, 第 52 号, pp. 135 138, 1989 年 6 月

7）近江 隆, 北原啓司, 広瀬浩二, 鳥居立弥：SUS の成立 に及ぼす建物・街路の影響, 日本建築学会東北支部研究 報告集, 第 53 号, pp. 71 74, 1990 年 6 月

8）日本建築学会大会学術講演梗概集において 1988，1989, 1990, 1991 年に, すでに7編の報告をしており，参照さ れたい。

(1991 年 6 月 10 日原稿受理, 1991 年 12 月 11 日採用決定) 